\title{
PENTINGNYA LITERASI MEDIA BAGI KAUM PEREMPUAN
}

\author{
Rahmi Mulyasih \\ Program Studi Ilmu Komunikasi Fakultas Ilmu Sosial dan Ilmu Politik \\ Universitas Serang Raya \\ Jalan Raya Cilegon-Serang Km. 5, Drangong, Serang, Banten \\ Email : bikiya16@gmail.com
}

\begin{abstract}
This study focuses on the importance of media literacy for women, this is because women are the main characters in a family, the young generation of quality born of the important role of women. This study used a qualitative approach with phenomenological research methods. The results showed that the low culture of literacy in women, which can ultimately result in terbiasany children watch the action Kekeran and low values of humanist obtained children from an early age, resulting in the shift of the culture and behavior of the young generation that is far from the value of -the value of religion and society.
\end{abstract}

Key Words: Media Literacy and Women

\section{PENDAHULUAN}

Perkembangan media terutama media baru seperti internet saat ini sangat pesat, kemunculan media sendiri di Indonesia diawali dengan media cetak kemudian berkembang kearah audio visual seperti radio dan televisi dan saat ini mulai dikenal dengan era media internet dimana dalam era ini masyarakat dapat dengan mudah mengakses informasi secara cepat. Keberadaan internet ini pula yang kemudian melahirkan interaksi komunikasi yang berubah bagi perkembangan kehidupan manusia, karena tidak lagi komunikasi dilakukan dengan bertatap muka namun dapat dilakukan melalui media sosial yang saat ini tengah digandrungi oleh masyarakat luas.
Literasi media adalah sebuah gerakan baru yang saat ini tengah marak di masyarakat, literasi media muncul karena arus informasi yang hampir tidak dapat dibendung, karena informasi dari media sosial yang baik dan buruk hadir di tengahtengah masyarakat terutama banyak dikonsumsi oleh anak-anak di bawah umur serta perempuan yang sangat rentan terterpa media sosial.

Oleh karena itu diperlukan adanya literasi media sosial bagi perempuan, untuk membentengi keberadaan informasi yang mengarah pada sisi negatif yang dapat berdampak buruk tidak hanya bagi diri perempuan itu sendiri tetapi juga bagi keluarganya terutama bagi anak-anaknya. Perempuan merupakan pondasi awal 
pembentukan karakter anak-anak, oleh karenanya anak mempelajari ilmu pertama kali dari ibunya. Sehingga diperlukan suatu literasi media yang cukup baik bagi perempuan agar dapat mengarahkan anakanaknya dalam menggunakan media sosial secara lebih bermanfaat.

Kurangnya literasi media sosial bagi perempuan pun dapat berdampak pada ke harmonisan dalam membangun hubungan dengan keluarganya, hal ini terlihat banyak kasus perceraian yang diakibatkan dari adanya interaksi komunikasi yang dilakukan di media sosial antara perempuan dan lawan jenis yang bukan keluarganya. Sehingga kaum perempuan harus lebih bijak dalam menggunakan media sosial, karena jika media sosial tidak digunakan dan dimanfaatkan dengan baik dapat berakibat pada komunikasi keluarga terganggu diantara setiap anggota karena para anggota keluarga lebih senang melakukan komunikasi di media sosial, selain itu media sosial harus dipergunakan menjadi ajakan kreatifitas dan menambah kualitas perempuan-perempuan di Indonesia lebih baik lagi.

Dari adanya fenomena literasi media dikalangan perempuan itulah, maka peneliti tertarik untuk mengangkat kajian dengan judul "Pentingnya Literasi Media Bagi Kaum Perempuan”.

\section{TINJAUAN PUSTAKA}

\section{Literasi Media}

Literasi dapat diartikan melek teknologi, informasi, politik, berpikiran kritis dan peka terhadap lingkungan sekitar. Kirsch dan Jungeblut dalam buku Literacy: Profile of Americs's Young Adult mendefinisikan literasi kontemporer sebagai kemampuan seseorang dalam menggunakan informasi tertulis atau cetak untuk mengembangkan pengetahuan sehingga mendatangkan manfaat bagi masyarakat. Baran (2004) menyebutkan saat ini literasi diartikan sebagai kemampuan memahami simbol-simbol tertulis secara efisien dan efektif serta komprehensif.Dengan adanya perkembangan media elektronik, maka kemampuan itu tidak bernama literasi lagi, tetapi menjadi literasi media (kecerdesan bermedia).

UNESCO (dalam Iriantara, 2006:79) mendefinisikan literasi dengan menyatakan: berdasarkan definisi UNESCO tahun 1958, literasi adalah kemampuan seorang individu untuk membaca dan menulis dengan memahami pernyataan singkat yang terkait dengan kehidupannya. Kemudian definisi ini berkembang sehingga meliputi ranahranah keterampilan jamak yang masingmasing dipandang memiliki taraf penguasaan yang berbeda dan melayani tujuan yang berbeda pula.Perkembangan sosial itulah yang membuat Lamb (dalam Iriantara, 2006) menyatakan bahwa literasi 
tidak hanya didefiniskan sebagai kemampuan membaca dan menulis, melainkan juga "kemampuan menempatkan, mengevaluasi, menggunakan dan mengkomunikasikan melalui berbagai sumberdaya termasuk sumber daya teks, visual, suara, dan video.

Alan Rubin (1998) menggabungkan beberapa definisi yang menekankan pengolahan kognitif dan informasi dan evaluasi kritis pesan. Dia mendefinisikan literasi media/melek media sebagai: pemahaman sumber teknologi dari komunikasi, kode yang digunakan, pesan yang diproduksi dan pemilihan, penafsiran serta dampak dari pesan tersebut. (Apriadi Tamburaka, 2013;8)

Silverblat mengidentifikasi lima elemen literasi media (Silverblat, 1995:2-3), yaitu:

1. Kesadaran akan dampak media pada individu dan masyarakat.

2. Pemahaman atas proses komunikasi massa.

3. Pengembangan strategi untuk menganalisis dan mendiskusikan pesan media.

4. Kesadaran atas konten media sebagai sebuah teks yang memberikan pemahaman kepada budaya kita dan diri kita sendiri.
5. Pemahaman kesenangan, pemahaman dan apresiasi yang ditingkatkan terhadap konten media.

Berdasarkan Centre For Media Literacy (2003) upaya untuk literasi media bagi khalayak adalah untuk mengevaluasi dan berpikir kritis terhadap konten media massa, mencakup :

1. Kemampuan mengkritik media.

2. Kemampuan memproduksi media.

3. Kemampuan mengajarkan sistem pembuatan media.

4. Kemampuan mengeksplorasi sistem pembuatan media.

5. Kemampuan mengeksplorasi berbagai posisi.

6. Kemampuan berpikir kritis atas isi media.

\section{Media Sosial}

Perkembangan media sosial saat ini cukup pesat, hal ini dikarenakan media sosial tidak hanya menghadirkan kemudahan informasi bagi penggunanya tetapi juga melahirkan pergeseran budaya bagi masyarakat Indonesia. Pengertian media sosial sendiri diartikan sebagai sebuah media online dengan para penggunanya (users) dapat dengan mudah berpartisipasi, berbagi dan menciptakan isi meliputi blog, jejaring sosial, wiki, forum dan dunia virtual (wikipidi). Blog, jejaring 
sosial dan wiki merupakan bentuk media sosial yang paling umum digunakan oleh masyarakat di seluruh dunia. Andreas Kaplan dan Michael Haenlein (2010;5968) mendefinisikan media sosial sebagai sebuah kelompok aplikasi berbasis internet yang membangun di atas dasar ideology dan teknologi web dan yang memungkinkan penciptaan dan pertukaran user generated content.

Gamble, Teri, dan Michael dalam Communication Works sebagaimana dikutip Wikipedia menyebutkan, media sosial mempunyai ciri - ciri sebagai berikut :

1. Pesan yang di sampaikan tidak hanya untuk satu orang saja namun bisa keberbagai banyak orang contohnya pesan melalui SMS ataupun internet

2. Pesan yang di sampaikan bebas, tanpa harus melalui suatu Gatekeeper

3. Pesan yang di sampaikan cenderung lebih cepat di banding media lainnya

4. Penerima pesan yang menentukan waktu interaksi

Media sosial yang populer digunakan di Indonesia antara lain

1. Facebok

2. Twitter

3. Youtube

4. $B \log$

\section{Google Plus}

Sebagai salah satu media komunikasi, media sosial tidak hanya dimanfaatkan untuk berbagi informasi dan ins pirasi, tapi juga ekspresi diri (self expression), "pencitraan diri" (personal branding), dan ajang "curhat" bahkan keluh-kesah dan sumpah-serapah. Status terbaik di media sosial adalah update status yang informatif dan inspiratif.

\section{Keluarga Yang Harmonis}

Pernikahan yang harmonis adalah pernikahan dua orang yang sama-sama dewasa, saling percaya, menghargai dan bersama menjalani kehidupan dengan citacita dan konsep yang sama. Menurut Rahman bahwa terdapat beberapa aspek yang perlu diperhatikan agar sebuah pernikahan akan terbentuk rumah tangga yang harmonis diantaranya adalah :

1. Memberikan rasa aman dan terhindar dari ketegangan. Karena didalam suatu bahtera rumah tangga, pasangan suami istri harus saling memberi dan merasa aman secara lahir maupun batin.

2. Saling memilik Dalam artian kedua pasangan tersebut harus merasa saling memiliki ikatan batin yang kuat, yang dapat menghubungkan dengan pasangannya. Cinta setia 
sehingga tercapai keselarasan diantara pasangan tersebut.

3. Saling menghargai. Dalam segala hal perlu adanya saling menghargai sebagai ungkapan perhatian untuk membangun harga diri dan keberhasilan pasangan.

4. Penuh kasih dan sayang. Maslow mengatakan bahwa salah satu kebutuhan manusia adalah akan rasa cinta kasih sayang (love need)dan kebutuhan ini juga ingin mendapatkan pemenuhan. Hal ini dapat berupa pujian, perhatian agar tercapai kebahagiaan dan dapat menikmati kebahagiaan serta merasa bersama.

5. Saling mempercayai. Hal ini sangat penting guna terciptanya kebahagiaan yang hakiki dan memberi kepercayaan yang utuh untuk kedua belah pihak agar mampu memahami dan mengerti, serta menghindarkan diri dari rasa curiga dan saling tuduh menuduh.

Sedangkan menurut Hawari, untuk menuju hubungan yang harmonis dan keluarga yang sehat, terdapat enam kriteria suatu pasangan, diantaranya yaitu:

1. Menciptakan kehidupan beragama dalam keluarga, sebab dalam agama terdapat nilai-nilai moral atau etika kehidupan. Penelitian di negara-negara maju mngemukakan bahwa keluarga yang tidak bernuansa religius, yang komitmen agamanya lemah dan keluarga-keluarga yang tidak mempunyai komitmen terhadap agama sama sekali, maka resiko empat kali untuk tidak berbahagia akan dialami dalam keluarga tersebut.

2. Menyediakan waktu bersama dalam keluarga, dengan kata lain waktu luang sangatlah penting artinya bagi keluarga, terutama bagi suami istri, akan tetapi terkadang orang tidak menyadari, sehingga waktu itu tidak

3. Melakukan interaksi segitiga, yaitu dengan cara menciptakan interaksi (hubungan) yang baik antar anggota keluarga, baik dengan bertatap muka ataupun dengan cara 
mencoba

untuk

berkomunikasi.

4. Saling menghargai dan berinteraksi, bahwa suami istri tidak lepas dari pekerjaan masing-masing, maka apa yang telah dikerjakan itu supaya keduanya saling menghargai. Keluarga sebagai unit terkecil, yang mana dalam keluarga terdiri dari ayah, ibu dan anak harus terikat erat dan kuat, jangan sampai longgar dan rapuh.

Kueluarga sebagai prioritas utama, yaitu apabila dalam keluarga mengalami krisis mungkin terjadi benturanbenturan, maka yang akan diprioritaskan terlebih dahulu adalah keluarga.

5. Saling memaafkan, hendaknya jika suami atau istri punya kesalahan hendaknya keduanya saling memaafkan, karena ini sangat penting untuk menjaga keutuhan dan keharmonisan rumah tangga.

6. Saling bermusyawarah, saling bermusyawarah dalam rumah tangga dapat menumbuhkan rasa memiliki dan rasa bertanggung jawab bersama. Karena itu, masingmasing pihak dituntut untuk jujur, terbuka dan berlapang dada, suka menerima dan memberi, serta tidak menang sendiri.

Islam memberikan berbagai anjuran dan perintah dalam menjaga kelanggengan dan keharmonisan rumah tangga, diantaranya adalah agar selalu berupaya memahami keadaan masing-masing, berharap sesuatu yang rasional, mengambil keputusan dengan perhitungan, hidup dengan menjaga nilai-nilai kebenaran, menajuhkan diri dari berbagai bentuk penyimpangan, menjaga hak-hak berlandaskan ketaqwaan. Dalam upaya mewujudkan keharmonisan dan keseimbangan dalam kehidupan rumah tangga. Islam senantiasa berupaya agar suami istri dan anak saling menghormati, saling menginginkan kebaikan, dan tidak melakukan sesuatu yang dapat mendatangkan bencana bagi diri mereka dan anak-anaknya.

\section{Teori Media Baru}

Sebagaimana yang dilihat perkembangan media di masyarakat, bahwa media baru yang dirasakan amat bermanfaat dan memiliki masa depan menjanjikan adalah media interaktif dan media jaringan. Kedua media ini telah 
merubah peradaban umat manusia terutama paradigma interaksi manusia satu dengan yang lainnya. Paling tidak ada dua hal yang menandai perubahan paradigma diatas,

Pertama, adalah media sebagaimana disebutkan Mcluhan adalah pesan itu sendiri, telah berubah menjadi subjek komunikasi yang sangat interaktif, dimana media telah menjadi sehabat baru manusia.

Kedua, interaksi manusia melalui media jaringan telah menciptakan ruang baru bagi kehidupan manusia yang disebut dengan cybercommunity yaitu sebuah "kehidupan" masyarakat manusia yang tidak dapat secara langsung diindera melalui (seluruh) penginderaan manusia, namun dapat dirasakan dan disaksikan sebagai realitas.

Perubahan paradigma interaksi manusia di atas membawa manusia kepada dunianya yang baru, yaitu sebuah dunia yang sangat kecil sekaligus sebuah dunia yang tanpa batas dengan pola-pola hubungan sosial yang sangat luas dan transparan. Inilah dunia masa depan umat manusia, sebuah dunia baru yang dikonstruksikan oleh media baru setiap saat, setiap waktu sehingga sebenarnya dunia masa depan adalah sebuah dunia yang berada di atas "telapak tangan" media.

\section{METODE PENELITIAN}

Penelitian menurut Nazir $(1988 ; 76)$ adalah proses, sedangkan ilmu pengetahuan adalah hasil dari penelitian. Oleh karena itu "bahasa dasar" bagi seorang peneliti ditemukan dalam bahasa filsafah ilmu, karena merupakan bangunan dasar suatu ilmu pengetahuan yang meliputi observasi, fakta, konsep, definisi, variabel, masalah, hipotesis, hukum, teori, dan model (Davis \& Cosenza).

Tipe penelitian ini adalah kualitatif, yaitu pendekatan yang berawal dari data yang bermuara kepada kesimpulan (Bungin, 2001;18), pendekatan kualitatif menurut Bagdon dan Taylor dalam Moleong (2002;3) adalah prosedur penelitian yang menghasilkan data deskriptif berupa kata-kata tertulis atau lisan dari orang dan perilaku yang diamati. Dalam pendekatan kualitatif data yang dihasilkan berbentuk kata, kalimat dan gambar untuk mengeksplorasi bagaimana kenyataan sosial yang terjadi dengan mendeskripsikan variabel yang sesuai dengan masalah dan unit yang diteliti, dalam hal ini adalah bagaimana mengkaji studi kasus yang diteliti.

Tahap permulaan dari metodelogi penelitian adalah menentukan tipe 
penelitian, yang didasarkan kepada metode penelitian yang dilakukan. Metode penelitian yang akan dilakukan menggunakan metode penelitian studi kasus hal ini dikarenakan dalam penelitian ini melihat banyaknya permasalahan yang ditimbulkan dari terpaan media yang ditimbulkan sehingga berakibat pada berubahnya tatanan kehidupan masyarakat sehingga diperlukan adanya literasi media bagi kaum perempuan agar dapat membentengi keluarganya dalam mengkonsumsi media.

Studi kasus sendiri menurut Stake (dalam Denzin, 2005: 445-446 ) merupakan metode penelitian yang menjelaskan keputusan-keputusan dalam studi kemudian mengimplementasikan dan setelah itu melihat hasilnya. Tipe dari penelitian studi kasus sendiri terdiri dari tiga tipe, yaitu (1) intrinsic case study, bila studi ditujukan untuk memperoleh pemahaman yang lebih baik dari suatu kasus tertentu; (2) instrumental case study, jika suatu kasus tertentu diteliti dengan tujuan utama untuk memperoleh pemahaman mengenai suatu isu atau untuk mendapatkan generalisasi sehingga bersifat sebagai pendukung dan memperjelas kasus lain; dan (3) multiple case study atau collective case study, bila beberapa kasus diteliti secara bersamasama untuk mendalami suatu fenomena, populasi, atau kondisi umum.
Dari tipe yang sudah dipaparkan, maka penelitian ini masuk ke dalam tipe penelitian intrinsic case study dimana dalam penelitian ini hanya mencoba menggali pemahaman mengenai seberapa besar literasi media bagi kaum perempuan, sehingga data-data yang telah terkumpul dapat memberikan pemahaman bagi kaum perempuan untuk lebih bijak dalam mengkonsumsi media dan menggunakan media sesuai dengan kebutuhannya.

\section{HASIL DAN PEMBAHASAN}

\section{Terpaan Media Bagi Kaum Perempuan}

Perkembangan teknologi komunikasi yang semakin pesat memunculkan mediamedia baru di lingkungan masyarakat kita, yang berdampak pada kemudahan di dalam mengakses informasi-informasi yang dibutuhkan oleh masyarakat. Literasi media atau melek media awal mulanya didefinisikan untuk meningkatkan kemampuan dalam membaca dan menulis, namun dalam teori komunikasi sendiri literasi media dipahami sebagai kemampuan untuk menganalisa berita secara kritis seperti kemampuan dalam hal menulis berita dan menyebarkan tulisan.

Seperti yang kita ketahui, bahwa perkembangan media yang pesat menimbulkan banyak dampak yang terjadi di masyarakat baik dampak positif maupun 
negatif. Dilihat dari dampak positif media memberikan kemudahan dalam mengakses informasi, seperti media televisi yang menggambarkan beragam informasi dari berbagai daerah di tanah air maupun manca negara bahkan televisi menghadirkan berbagai macam program acara yang dapat menghibur kaum perempuan contohnya saja tanyangan sinetron. Tayangan sinetron merupakan salah satu program acara yang paling digandrungi oleh kaum perempuan, hal ini dikarenakan kaum perempuan memiliki budaya yang unik, yaitu budaya senang "mengobrol" dengan orang lain. Pada mulanya obrolan masih bersifat hal-hal yang ringan, namun terkadang mengarah pada curhat permasalahan yang dihadapi, kemudian dengan berkembangnya teknologi komunikasi seperti televisi dan internet obrolan berkembang kearah gosip seputar selebritis yang terlibat masalah.

Informasi yang diberitakan oleh televisi, saat ini tidak lagi mengarah pada nilai-nilai pendidikan yang dapat mengembangkan kualitas sumber daya masyarakat, namun lebih mengarah kepada bisnis sehingga dunia televisi saat ini lebih didominasi oleh sinetron-sinetron yang mengumbar ke arah kehidupan masyarakat yang konsumtif dengan pergaulan remaja yang cenderung bebas sehingga melahirkan pergeseran budaya pada masyarakat kita. Oleh karena itu diperlukan adanya literasi media bagi kaum perempuan dimana ketika mereka menyadari bahwa televisi saat ini hanya mengkonstruksi keinginan pemilik media dan rating yang ada di masyarakat, untuk menjembatani hal tersebut kaum perempuan sebisa mungkin harus mendampingi anak-anak mereka dalam mengkosumsi media televisi. Dengan adanya hal tersebut diharapkan anak-anak sebagai generasi penerus bangsa tidak terkena terpaan media terlalu besar sehingga dapat merubah prilaku yang mengarah pada hal-hal yang bersifat negatif.

Infotaiment merupakan program acara yang paling disukai pula oleh kaum perempuan, hal ini dikarenakan infotaiment menyuguhkan informasi seputar kehidupan selebritis. Dengan adanya hal tersebut, terkadang kehebohan obrolan antar kaum perempuan muncul dikarenakan adanya informasi dari infotaiment. Infotaiment sendiri, menurut Bimo Nugroho di dominasi oleh dua kepentingan, yaitu kepentingan ekonomi bisnis dan politik kekuasaan. Kepentingan inilah yang mengakibatkan infotaiment tidak lagi menekankan pada posisi jujur, netral, adil, dan terbuka sesuai dengan ciriciri infotaiment yang disepakati. Ciri-ciri yang seharusnya diterapkan oleh pelaku industri media kedalam program acara 
infotaiment, mencakup hal-hal sebagai berikut:

a. Acara menyajikan informasi aktual atau rangkuman informasi dari suatu periode waktu tertentu (kilas balik) dari peristiwa yang terjadi di dalam dan luar negeri dan yang menambah wawasannya;

b. Acara yang ditayangkan secara berulang kali atau regular pada slot tetap;

c. Acara menyajikan informasi, tetapi dikemas dalam bentuk hiburan; dan

d. Termasuk informasi ringan seputar dunia selebritis, misalnya tentang profil selebritis (selebritis bukan hanya terbatas pada dunia hiburan, namun juga meliputi tokoh lainnya dari dunia olah raga, politikus dan lain-lain).

Kaum perempuan begitu menggandrungi infotaiment, karna ratarata kaum perempuan senang menonton kehidupan orang lain terutama selebritis dari sana mereka memperoleh gambaran kehidupan glamor para artis dan prilakuprilaku yang kemudian menjadi tolak ukur untuk mereka menerapkan hal-hal yang tengah hangat untuk dipergunjingkan pada saat mengobrol antar sesama kaum perempuan. Hal tesebut seperti yang dipaparkan oleh Media Sucahya sebagai pengamat media dan seorang akademisi yang menyatakan bahwa:
Media terutama untuk media sosial memang sangat berbanding lurus dengan kaum perempuan, hal ini dikarenakan informasi yang ada di media lebih dari mulut ke mulut, gossip dan membicarakan orang lain. (Senin, 3 Maret 2017)

Selain televisi, media lainnya yang sering digunakan oleh kaum perempuan adalah media baru seperti internet. Internet menjadi salah satu jaringan yang saat ini merajai kegunaan media di lingkungan masyarakat, karna dengan internet manusia dapat mengakses informasi yang dibutuhkan, termasuk untuk kaum perempuan. Dengan internet kaum perempuan dapat mecari informasi seperti kebutuhan mengenai resep makanan bahkan informasi yang dibutuhkan oleh anak-anaknya contohnya saja makanan pendamping ASI (MPASI), gejala penyakit yang diderita oleh balita dan lain sebagainya.

Penggunaan internet tidak hanya memberikan pemahaman mengenai media baru bagi kaum perempuan, namun dengan internet kaum perempuan pun dapat dengan mudah melakukan komunikasi yang biasanya sulit dilakukan dengan cara komunikasi antar pesona. Internet dengan jaringan komunikasi seperti twiter, fb, dan line melahirkan tidak hanya perubahan pada pola komunikasi kaum perempuan namun juga perubahan prilaku yag dialami 
oleh kaum perempuan. Keasikan menggunakan fasilitas yang ada di dalam jaringan komunikasi yang ada di internet berakibat pada ketergantungan kaum perempuan, yang berakibat pada terbengkalainya tugas kaum perempuan di tengah-tengah keluarga seperti tugas sebagai istri dan ibu karna keasikannya mengobrol, update status atau melakukan kegiatan lainnya melalui internet.

Oleh karena itu diperlukan adanya penggunaan literasi media terutama pada media sosial agar peran kaum perempuan dapat seimbang dalam menjalankan tugasnya di dalam keluarga dan kebutuhannya dalam memanfaatkan teknologi komunikasi. Hal ini seperti yang di paparkan oleh Wulan Ageng Triani seorang ibu rumah tangga dan penjual online yang menyatakan bahwa:

\begin{tabular}{|c|}
\hline $\begin{array}{l}\text { Dengan adanya kemudahan } \\
\text { teknologi } \\
\text { seharusnya kaum pemunikasi, } \\
\text { tidak menyalahi kodratnya } \\
\text { sebagai ibu dan seorang istri } \\
\text { ditengah-tengah keluarga, oleh } \\
\text { karena itu biasanya saya akan } \\
\text { mendahulukan kepentingan } \\
\text { dan kebutuhan keluarga } \\
\text { terlebih dahulu baru kemudian } \\
\text { pekerjaan lainnya seperti } \\
\text { melakukan penjualan online, } \\
\text { karna buat saya kebutuhan } \\
\text { keluarga lebih penting } \\
\text { dibandingkan dengan kegiatan } \\
\text { diluar keluarga (Senin, } 3 \text { Maret } \\
\text { 2017) }\end{array}$ \\
\hline
\end{tabular}

Kesadaran akan peran kaum perempuan akan kebutuhan media harus pula diseimbangkan dengan posisinya sebagai ibu dan seorang istri, karna banyak data menyebutkan bahwa meningkatnya kasus perceraian diakibatkan karena penggunaan media sosial. Media sosial memang menjadi daya tarik bagi kaum perempuan yang berakibat pada ketergantuagan jika tidak disikapi secara bijak. Oleh karena itu kaum perempuan harus dapat memprioritaskan kepentingan keluarga denga kebutuhan akan media.

\section{Pentingnya Literasi Media Bagi Kaum Perempuan}

Perempuan merupakan pondasi bagi keluarganya, karna awal pengetahuan anak-anak didapat dari seorang ibu. Terpaan media yang tidak terbendung berakibat pada perubahan prilaku pada generasi muda terutama anak-anak, banyak kasus yang melibatkan anak-anak disebabkan karena terpaan media. Seperti meningkatnya kasus pelecehan seksual yang pelakunya anak di bawah umur, kasus pembunuhuan hanya karna anakanak meniru aksi superhero yang menjadi idolanya seperti terbang dari lantai lima sebuah aparteman atau melakukan smakdone antar teman sebaya.

Dari banyaknya kasus yang menimpa anak-anak maka diperlukan adanya sikap kritis bagi kaum perempuan terhadap penggunaan media bagi anak-anak, 
sehingga dapat mengurangi terpaan media pada anak-anak dengan cara:

a) Mendampingi Anak-Anak Dalam Menonton Dan Mengakses Media Mendampingi anak-anak dalam menonton dan mengakses media perlu dilakukan oleh kaum perempuan terutama para ibu, hal ini bertujuan agar anak-anak dapat terpantau program acara apa saja yang layak dikonsumsi oleh anak-anak jangan sampai program acara yang ditujukan pada segmen dewasa malah dikonsumsi oleh anak-anak. Disinilah peran kaum perempuan dalam mengarahkan dan memberikan pengertian bagi anak-anaknya, mana tindakan yang baik dan buruk dari karakter yang di hadirkan oleh program acara anak-anak. Sama halnya dalam mengakses internet melalui gadget, karna kemudahan dalam penggunaan gadget sehingga memudahkan anak-anak untuk mengakses internet. Oleh karena itu dibutuhkan peran kaum perempuan dalam memantau dan mengawasi anak-anak dalam mengakses internet, jangan sampai anak-anak membuka situs-situs yang tidak seharusnya dikonsumsi oleh anak-anak.

Pentinnya pengawasan dan pendampingan kaum perempuan bagi anak-anaknya sangat diperlukan, hal ini seperti yang dipaparkan oleh Wulan Ageng Triani sebagai berikut:

Saya biasanya selalu mendampingi putri saya Aira pada saat menonton film kartun kesukaanya begitu pun ketika mengakses youtube di gadget, hal ini bertujuan untuk mencegah hal-hal negative yang ditimbulkan media (Senin, 3 Maret 2017)

Sisi positif dan negatif yang ditampilkan media sangat berpengaruh bagi kehidupan manusia, oleh karena itu diperlukan sikap kritis kaum perempuan dalam membentengi halhal negatif yang akan berdampak pada keluarga terutama anak-anak mereka.

b) Membuat Aturan Dalam Penggunaan Media

Penggunaan media perlu diberlakukan bagi setiap keluarga, pemberlakuan ini dapat disepakati antar anggota keluarga, karna bagaimana pun komunikasi efektif diantara setiap anggota keluarga sangat diperlukan dari pada pemanfaatan teknologi komunikasi. Namun fenomenanya banyak anggota keluarga yang berdekatan tetapi tidak dekat satu sama lain dikarenakan asik dengan handphone dan dunianya masingmasing.

Oleh karenanya diperlukan adanya peran kaum perempuan dalam 
mengarahkan keluarga dengan aturanaturan yang menjadi kesepakatan anggota keluarga misalnya saja anak boleh menggunakan gadget satu hari dalam seminggu atau ketika berada di rumah apa pun bentuk teknologi komunikasi tidak boleh digunakan, dengan adanya hal tersebut diharapkan komunikasi efektif diantara setiap anggota keluarga dapat berjalan dengan baik.

Dari hal-hal yang digambarkan diatas oleh karenanya sangat diperlukan adanya literasi media bagi kaum perempuan, agar dapat memberikan pemahaman dan mengawasi setiap anggota serta menyeimbangkan antara kebutuhan akan media dan posisinya sebagai seorang istri dan seorang ibu. Namun harapan agar kaum perempuan dapat melek media masih memerlukan perjalanan yang sangat panjang karna menurut Baran (1999) harus mencakup hal-hal sebagai berikut:

a) Mampu dan mau memahami isi, menaruh perhatian dan menyaring halhal buruk;

b) Paham dan respek pada kekuatan isi media;

c) Mampu membedakan sifat emosi rasa reaksi yang ditimbulkan ketika merespon pesan;

d) Memiliki tuntutan kualitas isi media yang tinggi; e) Memahami peraturan dan menyadari bila peraturan dilanggar atau dicampuradukan;

f) Mampu berpikir kritis tentang isi media dengan mengabaikan seberapa kridibel sumbernya; dan

g) Mengetahui bahasa internal berbagai media dan memahami efeknya.

Melek media yang dipaparkan oleh Baran, harus dipahami secara baik oleh kaum perempuan karena yang berperan penting dalam rumah tangga adalah ibu atau kaum perempuan, bukan laki-laki atau suami sebagai kepala rumah tangga. Oleh karenanya jika kaum perempuan tidak memiliki pemahaman yang baik tentang media dapat merugikan bagi perkembangan anak-anak mereka karna bagaimana pun fungsi media bukan sebagai alat pengasuh dalam menjaga anak-anak (electronic babysitter) namun sebagai penunjang peningkatan informasi dan hiburan dalam kegiatan manusia.

\section{KESIMPULAN}

Peran kaum perempuan dalam literasi media pada akhirnya memiliki peran yang sangat penting, hal ini dikarenakan ditangan kaum perempuan generasi muda berkualitas akan lahir. Oleh karena itu kaum perempuan harus memiliki pemahaman dan kesadaran yang baik mengenai literasi media jangan sampai 
karena kurangnya literasi media pada kaum perempuan mengakibatkan anakanak menyaksikan parade kekerasan dan perendahan nilai-nilai humanism dari terpaan media yang dikonsumsi.

\section{DAFTAR PUSTAKA}

Baran, Stanley J. 1999. Introduction to Mass Communication, Media Literacy and Culture. California: Mayfield Publishing Company.

Jane, Brown. D., Kim Walsh-Childers. 2002. "Effect of Media on Personal and Public Health" dalam Jennings Bryant, Dolf Zillmann (eds), Media Effects, Advances in Theory and Research. London: Lawrence Erlbaum Associates, Publishers.

Littlejohn, Stephen W. 2002. Theories of Human Communication. Wadsworth.

Nugroho, Bimo, Teguh Imawan, dkk. 2005. Infotainmen. Jakarta: Komisi Penyiaran Indonesia.

Potter, James. 2005. Media Literacy. Thousands Oak: Sage Publication.

Rakhmat, Jalaluddin. 2001. Psikologi Komunikasi. Bandung: Remaja Rosdakarya.

Tubbs, Stewart L., Sylvia Moss. 2001. Human Communications, Konteks-konteks Komunikasi. Bandung: Remaja Rosdakarya.

Veven Sp Wardhana. 2005. Sinetron Indonesia untuk Pasar dan Budaya. Yogyakarta: LP3Y. 